\title{
PENINGKATAN PRODUKTIVITAS MASYARAKAT MELALUI INDUSTRI KREATIF DENGAN PEMANFAATAN POTENSI SUMBER DAYA LOKAL DI DESA TIMBUOLO TENGAH GORONTALO
}

\author{
Muhammad Sayuti' ${ }^{1)}$, Hasanuddin ${ }^{2}$ \\ Jurusan Peternakan, Universitas Negeri Gorontalo ${ }^{1)}$ \\ e-mail: m.sayuti@yahoo.co.id \\ Jurusan Teknik Industri, Fakultas Teknik, Universitas Negeri Gorontalo ${ }^{2)}$ \\ e-mail: hasan76uddien@gmail.com
}

\begin{abstract}
The improvement of creative industry is guarantee for the local resources development base, such as it seems on the coconut commodity abundant as in Timbuolo Tengah Village. Coconut is a kind of plants cultivated and having a large benefits. This row input can be utilized by the society group for improving their productivities that supporting them having self-independence on economical aspect. The method used in achieving the aim is empowering the society through knowledge transfer and technology. This method is applied towards the society group target, such as learning strategy and equipping practice, and packaging technique and labeling and determination of length time of saving product (expired), the technique of depending sanitation, and marketing strategy, by being accomplished with the students collaborative with the society target and BP3K, also Guidance of Lecturer (DPL). The result of his activity are (1) the society gets knowledge improvement of the coconut variant product. (2) Obtaining the universal product development of coconuts, (3) increasing society productivity in arranging coconut production, (4) forming the coconut marketing opportunity based on the market segment that had been treated by students collaborative with the society group not only in the government office but also in the tourism area. This is the indication of the society effort sustainability later.
\end{abstract}

Keywords: Society Productivity, creative industry, the local resources, added economy value. 


\section{PENDAHULUAN}

Peningkatan Produktivitas Masyarakat Melalui Industri Kreatif Dengan Pemanfaatan Potensi Sumber Daya Lokal Di Desa Timbuolo Tengah Gorontalo. Sumberdaya lokal yaitu sumberdaya yang banyak terdapat pada daerah tersebut seperti kelapa. Desa Timbuolo Tengah memiliki potensi produktivitas sumber daya lokal seperti kultivar kelapa yang berkualitas tinggi (Tenda et.al, 2009) dan merupakan salah satu desa yang eksis dalam pengembangan kelapa dibandingkan dengan desa lain di sekitarnya luas kelapa $+33,4 \mathrm{Ha}$, sementara desa disekitarnya yaitu Desa timbuolo $10 \mathrm{Ha}$, Desa Timbuolo Timur 20,65 H. Produksi ini sangat menunjang masyarakat untuk lebih meningkatkan pendapatannya. Potensi pengembangan industri kreatif sangat menjanjikan untuk dikembangkan dengan melihat potensi sumber daya lokal seperti adanya tingkat produktivitas komoditas kelapa yang melimpah di desa Timbuolo Tengah serta desa sekitarnya sebagai pendukung. Dari data perkebunan tahun 2015 kecamatan Botupingge untuk komoditi kelapa yaitu tanaman menghasilkan (TM) 203,4 ha, tanaman belum menghasilkan (TBM) 52,1 ha serta tanaman tidak menghasilkan (TTM) 10,8 ha. Hanya saja permasalahan yang dihadapi oleh masyarakat adalah produksi yang belum optimal karena penyerapan hasil panen oleh pasar yang belum lancar, hasil panen perkebunan selama ini dilepas ke pedagang pengumpul dengan harga yang sudah ditentukan seadanya. Kondisi pemasaran ini menyebabkan petani sering mengalami kerugian dan melahirkan taraf kehidupan ekonomi yang pas-pasan. Pemanfaatan kelapa perlu pengembangannya dan pengolahannya baik kelapa yang menghasilkan maupun kelapa yang tidak menghasilkan, apalagi rata-rata masyarakat mata pencahariannya dengan berkebun kelapa. Walaupun produktivitas komoditas kelapa memiliki prospek dalam pengembangannya tetapi masyarakat masih mengalami kendala. Masalah yang dihadapi antara lain produksi yang belum optimal karena penyerapan hasil panen oleh pasar yang belum lancar. Hasil panen perkebunan kelapa selama ini dilepas kepedagang pengumpul dengan harga yang sudah ditentukan seadanya, kondisi pemasaran ini menyebabkan petani sering mengalami kerugian dan melahirkan taraf kehidupan ekonomi yang pas-pasan. Diperparah lagi dengan lamanya waktu panen buah kelapa berkisar + 3 (tiga) bulan, lamanya waktu panen tersebut tidak dimanfaatkan oleh masyarakat untuk mengelolah kelapa dalam bentuk produk lain untuk memenuhi kehidupannya dikarenakanm inimnya pengetahuan teknologi pengembangan pengolahan turunan produk kelapa, menambah suramnya ekonomi masyarakat petani ini terlihat dari kehidupan masyarakat yang masih dibawah garis kemiskinan. Beberapakelompok usaha pernah mencoba melakukan pengolahan produksi dari hasil komoditas perkebunan kelapasecara terbatas. Kegiatan pengolahan berhasil memperpanjang masa simpan produk dan terserap oleh pasar secara terbatas pula. Seperti kelompok usaha bersama "KUB Sari Kelapa" produk yang telah dihasilkan melalui kegiatan pengolahan adalah Virgin Coconut Oil (VCO), minyak klentik yang terkendala pada mutu dan pemasarannya. Salah satu karakteristik produk yang dipersyaratkan oleh pasar adalah disamping mutu yang bersifat konstan dan terstandar dengan penampilan kemasan yang menunjang serta suplai yang kontinyu. Kemasan belum bisa terpenuhi karena ketersediaan plastik botolan masih sulit diperoleh dan harganya relatif mahal. Akhirnya kelompok usaha bersama "KUB Sari Kelapa" mati suri, sehingga beralih kegiatan dengan perajin souvenir dan handycraft seperti pas bunga dan bingkai fhoto, yang melibatkan masyarakat remaja putus sekolah namun bahan bakunya didatangkan dari luar atau dibeli dan ini menimbulkan biaya (cost) yang besar, padahal seyogyanya bahan lokal 
seperti kelapa mulai dari akar sampai daun bisa dimanfaatkan dalam berbagai produk atau dijadikan bahan kerajinan. Permasalahan yang timbul dalam kelompok masyarakat selama ini, dan untuk mengatasinya dalam program KKN-PPM agar tetap eksis dalam peningkatan ekonomi lokal masyarakat adalah menggunakan metode mentransfer ilmu dan teknologi dengan melakukan pendampingan praktek langsung di lapangan mulai dari proses pengambilan bahan baku (kebun) sampai pada pemasarannya sehingga diperoleh keberlanjutan kegiatan secara kontinyu. Pendampinganpem berdayaan masyarakat yang dilakukan oleh mahasiswa selama program pelaksanaan KKN-PPM yang intensif, dan terarah serta tercapai tujuan dari permasalahan yang dialami masyarakat. Penempatan mahasiswa padaberbagai program dalam rangka pemetaan potensi dan masalah yang muncul serta solusi dan alternatifnya. Dari berbagai program yang direncanakan mahasiswa ditempatkan sesuai dengan kondisi masalah yang dialami. Program pemasaran yang terbanyak, karena program ini merupakan hal yang menjadi akhir dari pencapaian kegiatan yang menghasilkan nilai ekonomi. Pemasaran inilah yang sangat menentukan keberlanjutan kegiatan usaha masyarakat yang telah dilakukan pendampingan dalam program KKN-PPM disamping pola kinerja mahasiswa dalam pelaksanaan KKN-PPM. Indikator capaian produk Program KKN-PPM yang dituju adalah: 1). Peningkatan partisipasi dan kinerja produksi pada tingkat petani dalam rangka penyediaan bahan baku olahan ke kelompok usaha bersama masyarakat. 2). Peningkatan ekonomi lokal masyarakat dengan berbagai sentuhan teknologi pengolahan produk turunan kelapa. 3). Perbaikan sistem produksi kelapa

maupun pada teknik dan proses pengolahannya sehingga dihasilkan produk yang higienis dan bermutu. 4). Perbaikan teknologi alat dan perlengkapan saniter lainnya sehingga diperoleh efisiensi dan efektivitas proses. 5). Peningkatan partisipasi dan kinerja pendampingan oleh penyuluh $\mathrm{BP} 3 \mathrm{~K}$ dan pemerintah terkait sebagai mitra dalam program ini. 6). Partisipasi pasar swalayan di Kota Gorontalo menyerap produk secara berkelanjutan dan mengarahkan mutu produk olahan dan kerajinan kelompok usaha bersama "Posyantek "Bina Mandiri". 7). Luaran dari program ini adalah adanya teknologi proses pengolahan dalam pemanfaatan komoditas kelapa sebagai basis ekonomi lokal masyarakat yang berkelanjutan. Sedangkan hasil tema dalam jangka panjang program KKN- PPM ini adalah keberdayaan masyarakat melalui sentuhan ilmu dan teknologi pada komoditas perkebunan kelapa dalam menggerakkan sektor usaha/ekonomi masyarakat untuk peningkatan income perkapita, peningkatan indeks pembangunan manusia sehingga tercapai dalam pemenuhan bahan dasar (kebutuhan primer), peningkatan pengetahuan dan keterampilan penduduk pembangunan gender pada aspek partisipasi penduduk desa baik pria maupun wanita.

\section{KAJIAN LITERATUR}

Tanaman kelapa (cocos nucifera.L) termasuk dalam famili Palmaceae, subkelas monocotyledoneae. Tanaman kelapa ini sangat baik untuk daerah- daerah di sekitar khatulistiwa (iklim tropis dan subtropis) dengan ketinggian 0-500 meter di atas permukaan laut, terutama di daerah pantai. Pada ketinggian 800-1000 meter di atas permukaan laut, pertumbuhan kelapa lambat. Temperatur yang diperlukan untuk pertumbuhan yang baik adalah hasil penelitian produk olahan turunan kelapa seperti Virgin Coconut Oil (VCO), minyak klentik, gula merah dari nira kelapa, kecap air kelapa, Nata de coco dari limbah air kelapa, teknologi pembuatan santan pasta, dan hasil penelitian Hasanuddin, 2012 ampas kelapa dijadikan energi alternatif pengganti minyak tanah dalam bentuk biopelet. Banyaknya potensi produk turunan kelapa tersebut bisa dikembangkan 
dimasyarakat untuk meningkatkan ekonomi lokal masyarakat berkebun kelapa. curah hujan yang paling baik adalah antara 1542 mm sampai $2032 \mathrm{~mm}$ per tahun dan tidak kurang dari $1006 \mathrm{~mm}$ per tahun (woodroof, 2009). Menurut Kailaku, S.I, et al. (2009). Kelapa (Cocos Nucifera L.) merupakan komoditas perkebunan yang memiliki potensi pemanfaatan yang sangat luas, mulai dari kulit, sabut, daun, air hingga daging kelapa. Berbagai industri pengolahan keIapa seperti industri santan dan minyak kelapa meninggalkan ampas berupa daging kelapa parut

\section{METODE PENGABDIAN}

Model pemberdayaan dalam mentransfer ilmu dan teknologi pengembangan produk olahan turunan kelapa menggunakan metode pendampingan praktek langsung di lapangan mulai dari proses pengambilan bahan baku (kebun) sampai pada pemasaran produk yang melibatkan Dosen Pembimbing Lapangan (DPL) - mahasiswa - penyuluh lapangan (BP3K )- penduduk. Pelibatan penyuluh lapangan (BP3K) sebagai mitra dalam kegiatan KKN-PPM ini adalah merupakan lembaga yang sangat penting terkait kegiatan yang dilakukan dan berkecimbung dalam pembinaan pengembangan komoditas pertanian dan perkebunan. Sebelum bersosialisasi dengan penduduk mahasiswa terlebih dahulu dibekali dengan pengetahuan yaitu pembekalan.

\section{HASIL DAN PEMBAHASAN}

Kegiatan program KKN-PPM UNG 2017 yang berlokasi di Kecamatan Botupingge beberapa hal yang telah berhasil dilakukan atau dicapai dari rencana pelaksanaannya adalah kegiatan kebun, kegiatan pengolahan produk, kegiatan pengemasan, kegiatan kerajinan serta kegiatan pemasaran. Program - program tersebut telah dilaksanakan seperti :

\section{Kelompok kebun}

Perkebunan kelapa merupakan kegiatan yang dominan dilakukan oleh masyarakat Kec. Botupingge, tetapi dengan harga kelapa yang sangat murah dan waktu panen yang lama serta kurangnya pengetahuan tentang olahan turunan kelapa membuat masyarakat terjerap dengan ekonomi yang pas-pasan bahkan pada taraf kemiskinan. Pemahaman masyarakat secara tidak langsung diubah dengan adanyanya pendampingan pemberdayaan masyarakat yang dilakukan oleh mahasiswa melalui kegiatan $\mathrm{KKN}-$ PPM, harapan baru telah ditumbuhkembangkan mahasiswa kepada masyarakat tentang olahan turunan kelapa dengan mencari solusi yaitu peningkatan potensi sumberdaya alamnya terutama komoditas kelapa yang bernilai ekonomis. Pendampingan mahasiswa peserta KKNPPM bersama dengan penyuluh BP3K dan DPL pada kelompok perkebunan telah berjalan sesuai dengan rencana yaitu adanya animo masyarakat dalam membudidayakan kelapa dan kelompok masyarakat dapat mengetahui cara-cara pengambilan bahan baku untuk berbagai produk yang akan dikelolah serta meningkatnya volume produksi hasil berkebun dalam bentuk produk. Hal ini terlihat antusiasnya masyarakat dalam membudidayakan tanamannya dan memahami teknik budidaya dan pengambilan bahan baku untuk olahan. Ketercapaiannya rogram ini adalah 90\% masyarakat mensuplai hasil kebun kelapanya ke kelompok untuk diproses dalam bentuk produk.

\section{Kegiatan Pengolahan}

Kegiatan pengolahan merupakan kecakapan kelompok untuk mengolah kelapa menjadi produk yang bernilai untuk peningkatan penghasilkan masyarakat, adanya kegiatan KKN-PPM yang melibatkan mahasiswa untuk melaksanakan pendampingan sangat berarti yaitu dengan adanya pengetahuan baru tentang olahan kelapa baik dalam produk makanan atau minuman maupun produk aksesoris atau souvenir. Dengan penambahan pengetahuan dalam proses 
pengolahan memberikan asa bagikelompok untuk mengembangkan produknya dengan demikian bahwa peningkatan ekonomi secara langsung dapat mempengaruhi kehidupan dan tataran hidup masyarakat dan akan lebih giat untuk melakukan perubahan hidup. Adanya kegiatan ini menggambarkan bahwa masyarakat lebih eksis dalam mengolah kelapa dan turunannya yang lebih baik. Pendampingan mahasiswa pada masyarakat untuk pengolahan produk seperti VCO, Minyak Klentik, kue kelapa dan kelapa kering, santan kelapa dengan terlihat pada peningkatan ketrampilan kelompok, dan sudah mengetahui mutu olahan tersebut dan juga volume produksi olahan yang lebih baik. Ketercapain hasil program ini yaitu 90\% kelompok usaha telah memahami dan cakap dalam pembuatan produk olahan

\section{Kelompok Pemasaran}

Pemasaran merupakan suatu kegiatan untuk menentukan keberlanjutan usaha dalam peningkatan ekonomi lokal masyarakat dan keberlanjutan kegiatan kelompok karena muara keberhasilan usaha yaitu dengan dikenalnya produk Posyantek ditengah masyarakat luas dan banyaknya peminat atau konsumen. Hasil kegiatan yang dilaksanakan dalam proses pendampingan dalam program KKN- PPM ini adalah produk usaha mitra "Posyantek Bina Mandiri". Telah dieknal luas oleh masyarakat Gorontalo dan pemerintah serta adanya toko yang berciri khas untuk menerima produk - produk usaha baik produk olahan maupun dengan souvenir atau aksesoris, hal ini menunjukkan adanya peluang pemasaran. Mahasiswa sebagai pendamping dalam pemberdayaan 5 . masyarakat telah bersama-sama masyarakat kelompok melaksanakan kegiatan pemasaran baik secara preventif maupun pasif. Pemasaran preventif adalah penjualan langsung atau promosi ke calon konsumen hal ini dilakukan di daerah wisata pantai dan kantor pemerintah dan toko, tujuan utama adalah untuk mempopulerkan produk juga untuk memberikan wawasan atau pengetahuan cara-cara pemasaran yang akan dilakukan oleh kelompok dalam memasarkan produknya. Dengan pengetahuan ini diharapkankelompok masyarakat mampu meneruskan atau meningkatkannya dan melihat peluang pemasaran yang lebih baik. Pemasaran yang dilakukan di daerah wisata dan kantor pemerintah memberikan nilai positif yaitu pemerintah sangat mendukung kegiatan kelompok yang memiliki kreatifitas diri yang ingin maju dan berharap tetap eksis dan juga dukungan kepada mahasiswa yang melatih kelompok dalam pemasarkan produknya. Hasil capaian pemasaran ini adalah bahwa adanya MOU antara toko toko yang akan menampung dan menjual atau memasarkan produknya, selain itu juga masyarakat yang akan membutuhkan produk tersebut bisa langsung ke kelompok usaha masyarakat.

\section{KESIMPULAN}

Kegiatan program KKN-PPM yang dilaksanakan dapat disimpulkan bahwa :

1. Sebagian besar kegiatan ini sudah terlaksana atau tercapai dengan kemajuan kegiatan 90 $\%$ adanya antusias masyarakat dan siap untuk mengolah kelapa dan turunannya.

2. Kelompok masyarakat sudah memahami dan meningkatnya ketrampilan dalam mengolah turunan komoidtasa kelapa.

3. Program KKN-PPM merupakan kegiatan yang nyata dalam pendampingan pada masyarakat dalam mentransfer ilmu dan teknologi.

4. Keberhasilan program KKN-PPM ini adalah adanya MOU Antara toko - toko yang menjual ciri khas Gorontalo.

5. Produk - produk yang dihasilkan oleh kelompok sudah mulai dikenal luas oleh masyarakat

6. Adanya Pengetahuan strategi pemasaran yang akan dilakoni oleh kelompok untuk proses keberlanjutan usaha. 
6. REFERENSI

BP3K, 2012. Tanaman Kelapa Di kecamatan Botupingge. Workshop Kab. Bone Bolango

BPS, 2012. Kecamatan Botupingge Dalam angka. BPS Kabupaten Bone Bolango DP2M Dikti 2013 Panduan Penelitian dan Pengabdian Pada Masyarakat. Jakarta: DIKTI. Hasanuddin, 2012. Pembuatan

Biopelet Berbahan Ampas Kelapa Sebagai Bahan Bakar Alternatif Pengganti Minyak Tanah Ramah Lingkungan. Lemlit. UNG.

Kailaku, SI., Mulyawanti, I., Dewandari, K.T., Syah, A.N.A. (2009). Potensi
Tepung Kelapa dan Ampas Industri Pengolahan Kelapa. Prosiding Seminar Nasionl Teknologi Inovatif untuk pengembangan Industri Bebasis pertanian. Balai Besar Penelitian dan Pengembangan Pascapanen Pertanian. Bogor.

Tenda ET., Kumaunang J., Tulalo M, Manoroinsong E, Haju H dan Mahmud. 2009. Keunggulang dan Prospek Pengembangan Varietas Kelapa Dalam Molowahu dan Kelapa Dalam Kramat di Propinsi Gorontalo. Makalah untuk pelepasan Varietas Direktorat Perbenihan Ditjenbun. Balitka Manado 